\title{
Subject's Signature on Informed Consent
} Form

National Cancer Institute

\section{Source}

National Cancer Institute. Subject's Signature on Informed Consent Form. NCI

Thesaurus. Code C70958.

An inscription provided by a human subject on the informed consent document. This inscription signifies the subject's intent to participate in the clinical study, and his acknowledgement and understanding of the risks involved in such participation. 